\title{
A PROCESS OF DYNAMIC TRADE SHOW ACTIVITY MANAGEMENT WITHIN A REAL ESTATE DEVELOPMENT PROJECT LIFE CYCLE
}

\begin{abstract}
This paper presents a problem of the management of trade show activity in relation to the retail Real Estate development project life cycle of a huge shopping centre. Variability of that cycle in retail Real Estate business requires dynamic and flexible approach to the management of trade show activity, which is a complex process consisting of several stages. The aim of the paper is to recognise trade show activity of the retail Real Estate developers, who were not very experienced, in the duration of a full investment project life cycle of a big shopping centre. The research has included the activity of 6 large-sized shopping centre developers, who were not very experienced, in a period of about two and a half years. Throughout that time the developers participated in 7 consecutive trade shows for retail Real Estate market. There have been applied qualitative research methods: mystery visitor (as a type of participant observation) and unstructured interviews. Also, an analysis of information and advertising materials of the developers under research has been used. An analysis of the relation between the developers' activities performed at five stages of a project life cycle and trade show activity management at every of these stages has been explored and presented.
\end{abstract}

Keywords: B2B trade shows, trade show management, project life cycle, retail Real Estate development, participant observation.

\section{BACKGROUND}

A development activity of investment projects in the form of Real Estates with modern retail area can be categorised into a group of industrial services rendered by enterprises for enterprises (business to business - B2B). The purchasers and users of the services are entities that lease the floor space available in new shopping facilities. The most important tenants of shopping centres developed in Poland are, above all, international enterprises and a few domestic companies, which create retail trade networks and offer their own popular and strong brands. Those entities, which are called anchor tenants, lease the largest shopping spaces with the area ranging from $500 \mathrm{~m} 2$ to even $10,000 \mathrm{~m} 2$ and represent mainly retail trade businesses selling goods connected, for example, with: groceries, home and garden furnishings, household appliances, audio and video devices, sport, clothes and shoes.

\footnotetext{
${ }^{1}$ Dariusz Siemieniako, PhD, Department of Marketing and Entrepreneurship, Faculty of Management, Bialystok University of Technology, ul. O.S. Tarasiuka 2, 16-001 Kleosin, Phone: + 48 (85) 74698 21, e-mail: d.siemieniako@pb.edu.pl (corresponding author).

${ }^{2}$ Marcin Gębarowski, PhD, Department of Marketing, Faculty of Management, Rzeszow University of Technology, Al. Powstańców Warszawy 8, 35-959 Rzeszów, Phone: + 48 (17) 865 14 74, e-mail: marcing@prz.edu.pl
} 
For above 5 years, the Polish development market in modern shopping areas has been perceived as the mature market with established investment project management rules. Having considered, for instance, the diversification of project management processes, one can distinguish the following types of modern shopping facilities: a shopping centre, an outlet, a retail park, a strip mall and a high street ${ }^{3}$. The authors of this paper have focused on the activity of the developers which developed medium- and large-sized shopping centres, i.e. with Gross Leasable Area (GLA) of above 25,000 m2. B2B services rendered by this type of entities display the following characteristics: great complexity and diversification of processes, constant contact between a developer and potential tenants, long duration of a full service cycle, a considerable developer's risk, a high level of developer's capital commitment ${ }^{4}$.

The maturity of the Polish development market in large shopping centres shows diversified management processes with regard to this type of investment projects. They are carried out by experienced developers or the developers who have very little experience in the business. The first group includes predominantly international entities which offer not only development services, but also a wide range of services that support the growth of investment projects. The other group encompasses almost entirely domestic entities which - due to the fact of possessing a Real Estate situated in an attractive location suitable for a shopping facility - frequently decided to choose a strategic option related to investing in and developing a shopping centre. In the Real Estates intended for such facility, many of those entities had run before business activities connected with manufacturing or warehousing. Such entities perceive going into retail Real Estate development business as a one-time opportunity, rather than a long-term development strategy. However, there are examples of enterprises which have attained a competitive position in the business and remained permanently in it. High standards of the management of complex and usually risky investment projects necessitate, especially in the case of the developers who have little experience, making use of services provided by a number of specialist entities, for example lease brokers, legal and financial advisers, companies offering technical expert opinions, market research and analysis, architecture services or construction works. This paper presents the results of the research that has examined the trade show activity of the entities representing the second group of developers. For this group, participation in trade shows - apart from direct sale - is one of the most important forms of marketing activities conducted in order to lease area in shopping centres.

Having considered the medium term perspective of trade show activity planning, the dynamic management of exhibit activity in a variable investment project life cycle is a serious research problem. The aim of the paper is to recognise the trade show activity of the developers that are not very experienced, which occurs in the duration of a full investment project life cycle of a big shopping centre. There have been applied qualitative research methods, including participant observation and an unstructured interview. Furthermore, information and advertising materials of the developers under research have been analysed.

\footnotetext{
${ }^{3}$ Nowe obiekty zmieniaja układ sił na mapach handlowych glównych miast, "Rynek handlowy w Polsce - II kw. 2013", Jones Lang LaSalle, p. 2, http://qbusiness.pl/uploads/Raporty/jllhandel22013.pdf (accessed on: 8 July 2014).

${ }^{4}$ D. Siemieniako, Model zarzadzania lojalnościa relacyjna oparta na zobowiazaniu w zwiazkach uslugowych, "Marketing i Rynek" 2012/5, p. 8.
} 


\section{TRADE SHOW ACTIVITY MANAGEMENT WITHIN A PROJECT LIFE CYCLE - LITERATURE REVIEW}

The concepts of project and project management have been known and widely used for a long time, both in theory and practice ${ }^{5}$. According to Westland, project management is a combination of specialist knowledge, skills and experience necessary to reduce a risk throughout the project execution phase, as well as a set of various types of tools used by project managers ${ }^{6}$. Project management is also a series of different processes and techniques required to monitor and control the time, costs, quality and scope of a project. Lester proposed a definition of project management, which is a compilation of several definitions existing in the literature on the subject and contains all relevant elements. According to the author, project management is "the planning, monitoring and control of all aspects of a project and the motivation of all those involved in it, in order to achieve the project objectives within agreed criteria of time, cost and performance"

One can claim that projects go through a life cycle, from beginning to end. Projects may differ with regard to a size, diversification of activities and complexity, or in other words, the level of the intricacy of activities which require from contractors to have high qualifications. A project life cycle can be divided into stages which have their own unique features. Referring to the norms of British BS 6079 standards, Lester distinguishes 8 project life cycles ${ }^{8}$ :

1) "concept: basic ideas, business case, statement of requirements, scope;

2) feasibility: tests for technical, commercial and financial viability, technical studies, investment appraisal, DCF, etc.;

3) evaluation: application for funds, stating risks, options, TCQ criteria;

4) authorization: approvals, permits, conditions, project strategy;

5) implementation: development design, procurement, fabrication, installation, commissioning;

6) completion: performance tests, hand-over to client, post project appraisal;

7) operation: revenue earning period, production, maintenance;

8) termination: close-down, decommissioning, disposal."

A different and simpler approach to the project life cycle was presented by Westland, who sets forth four phases: initiation, planning, execution and closure ${ }^{9}$. In order to define

\footnotetext{
${ }^{5}$ L. Lindkvist, J. Söderlund, F. Tell, Managing product development projects: On the significance of fountains and deadlines, "Organization Studies" 19/6 (1998), p. 931-951; J. Packendorff, Inquiring into the temporary organization: New directions for project management research, "Scandinavian Journal of Management" 11/4 (1995), p. 319-333; Hodgson D., Cicmil S., The politics of standards in modern management: Making 'the project' a reality, "Journal of Management Studies" 44/3 (2011), p. 431-450; J. Söderlund, Theoretical foundations of project management: Suggestions for a pluralistic understanding, [in:] The Oxford handbook of project management, ed. P.W.G. Morris, J.K. Pinto, J. Söderlund, Oxford University Press, Oxford 2011, p. 37-64; M. Hällgren, A. Söderholm, Project-as-practice: New approach, new insights, [in:] The Oxford handbook of project management..., p. 500-516.

${ }^{6}$ J. Westland, The Project Management Life Cycle: Complete Step-by-Step Methodology for Initiating, Planning, Executing \& Closing a Project Successfully, Kogan Page, London 2006, p. 3.

7 A. Lester, Project Management, Planning and Control: Managing Engineering, Construction and Manufacturing Projects to PMI, APM and BSI Standards, Butterworth-Heinemann, Jordan Hill 2007, p. 5.

${ }^{8}$ Ibidem, p. 37.

${ }^{9}$ J. Westland, op. cit., p. 4-15.
} 
the life cycle processes of a huge and complex development project, the authors have adopted this division.

Mainela and Ulkuniemi indicate three levels of personal interaction, which constitute the components of relationship management in business projects: person-to-person interactions, relationship and community ${ }^{10}$. Relationship management, referred to as partnering in development projects, is presented as an essential factor of success in project performance $^{11}$. In construction project relationship management Meng indicated the project partnering which represents short-term collaborative relationships, and strategic project partnering which describes the long-term collaborative relationships ${ }^{12}$.

Trade show participation management is poorly described in the domestic literature on the subject. Similarly, the publications written by foreign authors devote very little attention to this issue as well. Very often, the exhibit activity management is presented from the angle of a single trade show performance ${ }^{13}$. And this fact has to be considered narrowing down, since a management perspective is limited in this case only to the activities performed during one trade show. Taking into account such a narrow presentation, within the process of preparing and giving a trade show performance one distinguishes the following stages: defining goals of the participation in trade shows, selecting a particular exhibit event, approving a budget, arranging and preparing a stall, creating advertising materials, selecting and training personnel, participation in the trade show (the exact trade show performance), follow-up activities. The above-mentioned process consists of the stages which include more detailed activities, repeated cyclically during consecutive trade show performances ${ }^{14}$.

However, the exhibit activity management can be understood in a broader sense from the point of view of the whole marketing activities performed by one exhibitor during many events. Trade shows should not be used as a one-off, ad hoc activity. They can be used more effectively when: 1 ) they are viewed as a possible series of exhibitions; 2) they are integrated carefully with other communications tools; 3 ) they are selected and planned well in advance; and 4) their effectiveness is constantly measured ${ }^{15}$. Such strategic approach includes the long-term utilisation of exhibit marketing in order to achieve effectively goals of an organisation. Consequently, the participation in particular trade shows is not accidental (it results from the strategy which had been adopted before) and serves as a complementary element of the activities carried out during other trade show

${ }^{10}$ T. Mainela, P. Ulkuniemi, Personal interaction and customer relationship management in project business, "Journal of Business \& Industrial Marketing" 28/2 (2013), p. 105.

11 A.M. Odeh, H.T. Battaineh, Causes of construction delay: traditional contracts, "International Journal of Project Management" 20/1 (2002), p. 67-73; X. Meng, The effect of relationship management on project performance in construction, "International Journal of Project Management" 30/2 (2012), p. 188-198.

${ }^{12}$ X. Meng, op. cit., p. 194.

${ }^{13}$ For instance: B. Siskind, Powerful Exhibit Marketing: The Complete Guide to Successful Trade Shows, Conferences, and Consumer Shows, John Wiley \& Sons Canada, Mississauga 2005, p. 1-2; P. de Pelsmacker, M. Geuens, J. van den Bergh, Marketing Communications: A European Perspective, Pearson Education, Harlow 2010, p. 511-515; A. Batko, A. Borcuch, A. Mochoń, M. Piłat-Borcuch, U. Świerczyńska-Kaczor, Rynek targowy: scena wystawców i organizatorów, Wydawnictwo Uniwersytetu Humanistyczno-Przyrodniczego Jana Kochanowskiego, Kielce 2010, p. 13-14.

${ }^{14}$ M. Gębarowski, Współczesne targi. Skuteczne narzędzie komunikacji marketingowej, Regan Press, Gdańsk 2010, p. 74.

${ }^{15}$ P.R. Smith, Z. Zook, Marketing Communications: Integrating Offline and Online with Social Media, Kogan Page, London 2011, p. 403. 
performances. Furthermore, such management perspective makes it possible to maintain cohesion between exhibit activity and promotion of all types (advertisement, personal sale, promotion of sale, public relations).

In the context of the subject of this paper, the key determinant of the trade show activity management - understood in a broader sense - is the area of the market on which an exhibitor occurs (B2B and B2C markets). The stage of a development project life cycle, which is being executed while taking part in a trade show, is also important.

It is accepted in the literature on the subject that trade shows play a special role in the marketing activities conducted by the entities which operate on the business-to-business market. The researches that have been carried out cyclically for more than several years by a German organisation, AUMA (Ausstellungs- und Messeausschuss der Deutschen Wirtschaft), demonstrate that economic trade shows and exhibitions are mentioned as the second (the first place is occupied by personal sale) most useful communication instruments for the attainment of sales goals on B2B markets. For the enterprises representing this sector, it is particularly important that the trade shows - owing to the fact that exhibitors can talk directly with visitors - let explain the complexity of products (including services) in a more efficient manner, compared to the majority of other communication instruments ${ }^{16}$. The exhibitors from business-to-business area should take into consideration the differences between B2B and B2C markets ${ }^{17}$. This entails, predominantly, adjusting a stall and the concept of offer positioning to the needs of customers from B2B sector, giving a proper form to a trade show performance so that there is an opportunity to hold discussions with specialists, ensuring appropriate preparation (factual knowledge) of the team representing an exhibitor, gathering detailed information on potential customers (in the context of prospecting), conducting follow-up activities consistently and completely ${ }^{18}$.

Within the exhibit activity management, a developer attempts to attain diversified marketing goals at each individual stage of a project life cycle, which necessitates modifying the components of his trade show performances - both physical components (stalls, showpieces, advertising materials) and non-physical elements (interactions with customers, atmosphere during discussions). The developers' trade show performances can reflect three dimensions: informative, promotional and commercial. Depending on the stage of a project life cycle, each of the dimensions strongly prevails or they occur to a similar extent. When the informative dimension is dominant, an exhibitor pays attention, first of all, to matter-of-fact argumentation, supporting a trade show demonstration with printed advertising materials and multimedia presentations. Should the promotional aspect be prevailing, a broad spectrum of the forms of influence on potential customers is used, as well as an appropriate atmosphere at a stall is created (according to the assumptions of experiential marketing). Contrary to the above, the commercial dimension concentrates on having more secret discussions, whose aim is to make a transaction.

\footnotetext{
${ }^{16}$ S. Jensen, A. Nuneva, Trade show as a brand management instrument in the B2B sector, [in:] Trade Show Management, ed. M. Kirchgeorg, W. M. Dornscheidt, W. Giese, N. Stoeck, Gabler, Wiesbaden 2005, p. 1085.

${ }^{17} \mathrm{Ph}$. Kotler, W. Pfoertsch, B2B Brand Management, Springer, Berlin-Heidelberg 2006, p. 20-34.

${ }^{18}$ M. Gębarowski, Zarządzanie udziałem $w$ targach $w$ kontekście działań marketingowych realizowanych na rynku B2B, [in:] Zarządzanie wobec współczesnych wyzwań społeczno-ekonomicznych. Księa jubileuszowa dedykowana Profesorowi Janowi Adamczykowi, ed. J. Wiażewicz, Oficyna Wydawnicza Politechniki Rzeszowskiej, Rzeszów 2013, p. 79.
} 


\section{RESEARCH METHOD}

As a research method, participant observation has been chosen, which can be categorised as a qualitative research method. Enterprises with a Polish capital, which were inexperienced or had very little experience in a retail Real Estate development business, served as research units, whereas decision-makers, project managers and board members, who were employed in those organisations, were subjects of the research. The research included 6 enterprises which were developing new (medium- or large-sized) shopping centres in Polish cities, with gross leasable areas (GLA) of 25,000 to $50,000 \mathrm{~m}^{2}$. One of the enterprises under research, was developing two shopping facilities simultaneously, and the remaining companies were implementing one investment project. Some of the enterprises had run before manufacturing activity in the buildings located on the premises of the shopping centres to be developed. When the attractiveness of the land increased, its administrators and owners decided to carry out a development project related to a shopping activity. In the contrary to the above case, the other enterprises, which represented diverse businesses (such as development housing services), purchased the rights to Real Estates in order to develop a shopping centre.

The field research was conducted by one of the authors of this paper, who additionally, throughout the research period, was dealing with the project management of a huge shopping centre in a practical sense. The duration of the research was about two and a half years - from September 2011 to February 2014. It covered 7 consecutive cyclical exhibit events devoted to retail Real Estate market, including 2 world's biggest retail Real Estate trade shows, MAPIC, organised in Cannes (France), as well as 5 biggest trade shows held in Poland and East-Central Europe, Shopping Center Forum (SCF) - 3 autumn and 2 winter editions. The participation in the cyclical trade shows enabled the observation of the changes that occurred in development project execution and marketing activity of 6 indicated developers, whose representatives were present during the most of the trade show events in which the researcher also took part.

The basic method applied in the research was one of the varieties of participant observation - i.e. a mystery visitor ${ }^{19}$. Also, a few other qualitative methods have been used, such as unstructured interview, opinion poll, analysis of secondary materials (including trade publications and informative and advertising materials of the developer under research). For the mystery visitor method, observation questionnaires served as research tools. Furthermore, the researcher used a scenario of unstructured interview. The data collected from the observation questionnaires has been quantified and analysed. Regarding the unstructured interviews, the researcher took notes immediately after the interviews had been conducted. The approach adopted by the author can be called as triangulation, since many qualitative research methods were applied in different periods of the research $^{20}$. It fits squarely into an interpretive and symbolic paradigm of management sciences, which has been based, among other things, on the social constructionist epistemol$\operatorname{ogy}^{21}$.

\footnotetext{
${ }^{19}$ M. Gębarowski, D. Siemieniako, Targi rynku nieruchomości handlowych w świetle badań metoda obserwacji uczestniczacej, "Marketing i Rynek" 2014/9, p. 33-39.

${ }^{20}$ A.G. Woodside, E.J. Wilson, Case study research methods for theory building, "Journal of Business and Industrial Marketing" 18/6 (2003), p. 498.

${ }^{21}$ Ł. Sułkowski, Paradygmaty nauk o zarządzaniu, "Współczesne Zarządzanie" 2013/2, p. 21.
} 


\section{RESULTS}

The research results have been presented in addition to connecting each stage of a project life cycle with goals and activities referring to the trade show activity of exhibitors at individual stages. Such model enables to present systematically the developers' under research attitude towards the trade show activity management - both in the whole life cycle of the project and at individual stages of the cycle.

Table 1 illustrates the stages of a retail Real Estate development project life cycle and project management processes that comprise individual stages. Moreover, a typical duration of the stages, expected by customers, has been presented. For each stage of the project life cycle, the table shows also the dimensions of the trade show activity performed by the exhibitors that are the shopping centre developers, entering into the market and having little experience.

Table 1. The dimensions of exhibitors' trade show activity in a typical development project life cycle of a huge shopping centre

\begin{tabular}{|c|c|c|c|}
\hline $\begin{array}{l}\text { The stages of } \\
\text { a retail Real } \\
\text { Estate devel- } \\
\text { opment pro- } \\
\text { ject life cycle }\end{array}$ & $\begin{array}{c}\text { Project management processes com- } \\
\text { prising individual stages }\end{array}$ & $\begin{array}{c}\text { The } \\
\text { duration } \\
\text { of a } \\
\text { stage }\end{array}$ & $\begin{array}{l}\text { The dimensions of the } \\
\text { trade show activity of } \\
\text { the exhibitors who are } \\
\text { entering into shopping } \\
\text { centre development } \\
\text { market }\end{array}$ \\
\hline $\begin{array}{l}\text { I. Project } \\
\text { initiation }\end{array}$ & $\begin{array}{l}\text { From identifying a development project as } \\
\text { a strategic option to verifying the project } \\
\text { as an attractive market opportunity for an } \\
\text { investor }\end{array}$ & $\begin{array}{l}\text { For } 1 \\
\text { year }\end{array}$ & $\begin{array}{l}\text { - informative (gathering } \\
\text { information) }\end{array}$ \\
\hline $\begin{array}{l}\text { II. Project } \\
\text { planning }\end{array}$ & $\begin{array}{l}\text { From the investor's decision about com- } \\
\text { mencing the project planning to obtaining } \\
\text { a positive appraisal of project execution } \\
\text { conditions }\end{array}$ & $\begin{array}{l}1.5-3 \\
\text { years }\end{array}$ & $\begin{array}{l}\text { - informative (as above) } \\
\text { - promotional (propagat- } \\
\text { ing an idea, project, } \\
\text { creating an image) }\end{array}$ \\
\hline $\begin{array}{l}\text { III. Preparatory } \\
\text { execution }\end{array}$ & $\begin{array}{l}\text { From taking on first considerable finan- } \\
\text { cial obligations (e.g. placing an order for } \\
\text { the preparation of architectural design) to } \\
\text { declaring the readiness for ordering main } \\
\text { construction works }\end{array}$ & $\begin{array}{l}1.5-2 \\
\text { years }\end{array}$ & $\begin{array}{l}\text { - informative (as above) } \\
\text { - promotional (as above) } \\
\text { - commercial (negotia- } \\
\text { tions, carrying out a } \\
\text { transaction) }\end{array}$ \\
\hline $\begin{array}{l}\text { IV. Real exe- } \\
\text { cution }\end{array}$ & $\begin{array}{l}\text { From ordering main construction works to } \\
\text { receivinga certificate of occupancy }\end{array}$ & $\begin{array}{l}1.5-2 \\
\text { years }\end{array}$ & - mainly commercial \\
\hline $\begin{array}{l}\text { V. Project } \\
\text { closure }\end{array}$ & $\begin{array}{l}\text { From opening the shopping centre to } \\
\text { finishing the processes of execution, } \\
\text { commercialisation and financing }\end{array}$ & $\begin{array}{l}3-6 \\
\text { months }\end{array}$ & - mainly commercial \\
\hline
\end{tabular}

Source: Own elaboration.

The duration of stage I (initiation) can be completely different - 1 year, and even 5 or 10 years. A potential developer can observe and analyse the situation of an enterprise and micro and macro environment from the perspective of the readiness for the decision to initiate a development project. The results of the participant observation showed characteristic activities of the developers under research, which were carried out for stage I:

- conducting market research and analysis, 
- identifying and analysing key factors conditioning the project execution, including for example: the absorption rate of the market - consumers and competition, the level of the Real Estate market attractiveness, adjusting communication system in the vicinity of the Real Estate, chance to get the financing of the project, the level of the competence and experience of own resources with regard to feasibility to implement the project,

- preparing a preliminary architectural conceptual design of the project and its strategic indications,

- testing the conceptual design among people from the business, in particular among experts and the representatives of shopping networks.

Within stage I, the developers attain the following goals connected with trade show activity:

- becoming acquainted with mechanisms and situations in the retail Real Estate business,

- getting to know expert opinions from the business, which refer to a preliminary concept of a shopping centre,

- gathering information - especially about tenants and existing and potential customers. The participation of the developers under research in the trade shows was either a public or secret action, depending on whether they preferred to reveal their own intentions of shopping centre development or not. In the case of the public trade show activity, it is possible to arrange a meeting between a developer's representative and entities - especially experts - which are interesting for him or her.

At stage II (planning), the developers usually performed the following activities:

- ensuring material, financial and human resources; creating conditions for operating in a proper legal and organisational structure,

- conducting market research and analyses by themselves and by using specialist entities,

- selecting a commercialisation agent in order to test the tenant market,

- ordering and preparing an architectural conceptual design with visualisations,

- preparing a strategic plan consisting of the following parts: (i) market analysis, (ii) commercialisation plan, (iii) promotion plan, technical execution plan, (iv) schedule, (v) financial plan,

- commencing the commercialisation - it is possible to conclude at this stage rental agreements with the entities that sell grocery items or house and garden furnishings, which require large areas for their business activities,

- commencing promotional activities (including public relations) of the project,

- ending all existing relationships due to which the Real Estate has to incur costs,

- taking advantage of or evaluating positively the opportunity to fulfil basic conditions of project execution.

Apart from the informative dimension, the objectives of the participation in trade shows at the planning stage had also the promotional aspects:

- gathering information about the situation in the business, financing, tenants, competitors and customers,

- getting acquainted with opinions, in particular the ones expressed by tenants, regarding the architectural conceptual design of the shopping centre, 
- making the concept of the shopping centre recognisable,

- supporting the act of concluding rental agreements with the key anchors, for example with an entity selling grocery items or house and garden furnishings,

- forming personal relationships with people from the business.

Throughout stage II, the representatives of the developers under research took part in the trade shows as visitors, the most often in the presence of a commercialisation agent, who provided professional support regarding the lease of shopping area. Trade show meetings had been usually arranged before an event began, however, ad hoc meetings took place as well. The developers' representatives presented technical and advertising materials and promoted their own projects in relation to basic parameters, i.e. a location, information about the market, communication availability, zones of influence, a size, an advantage over competitors.

Within stage III (preparatory execution), the developers under research indicated the following most important activities:

- performing promotional activities (including public relations),

- conducting commercialisation (including concluding the rental agreements with the key tenants),

- obtaining an approval for the project financing,

- producing an architectural building permit and/or detailed design,

- creating an interior design and land development plan,

- receiving a building permit,

- selecting specialist entities for the execution of the project, among others: the general contractor, a tenant coordinator, building control officers, a law office to support commercialisation process,

- carrying out preparatory construction works (e.g. demolition, clearing the Real Estate). The biggest trade show activity of the developers under research was precisely during the preparatory execution of the project. Additionally, the commercial dimension of the participation in the trade shows occurred at this stage. Therefore, the objectives of the trade show activity concerned:

- gathering information about the situation in the business, financing, tenants, competitors and customers,

- building the credibility of the development project,

- informing tenants about the progress in the construction of the shopping centre,

- speeding up the process of concluding rental agreements with a bigger group of potential anchor tenants,

- strengthening the personal relationships with other trade show participants.

Similarly to the previous stage, the developers' representatives were accompanied during the trade shows by a commercialisation agent. It was of great importance to arrange the meetings in advance. The high point of the developers' trade show activity throughout the whole project life cycle involved using their own stalls, where the final visualisation of the project was presented in various forms, such as: a mock-up, multimedia presentations, printed materials, touch screens. The developers under research used their own stalls once or twice in a row during two consecutive trade show events. It was a common fact that the exhibit stalls were for the first time presented at the biggest trade show in Poland - SCF, during the autumn edition, and sometimes for the second time during the winter edition (which is smaller than the one organised in autumn). The developers were 
given assistance from several commercialisation agents, law office representatives and interior designers. At stage III, the developers promoted during the trade shows the shopping centres under development process, putting a heavy emphasis upon the interior design and the progress in commercialisation. They presented the offer using various forms of printed advertising materials and trade show accessories. After closing their own stalls, they carried out short- and long-term activities intended for fulfilling the promises made during the trade shows.

At stage IV (Real execution), the developers performed the following activities:

- technical execution of the shopping centre,

- commercialisation of the whole project,

- financial support of the investment,

- management of the Real Estate during the technical execution,

- coordination of shopping centre tenants,

- preparation of the shopping centre for the opening,

- process of obtaining the certificate of occupancy (an administrative procedure),

- preparation for handing-over the administrative control of the facility after its opening. The trade show activity objectives were achieved mainly in the commercial dimension, and they involved:

- maintaining the credibility of the project,

- speeding up the process of concluding rental agreements with all potential tenants representing particular target groups,

- informing tenants about the progress in the technical execution and commercialisation.

The aim of the developers' participation in the trade shows as visitors was to complete negotiations with precisely indicated potential tenants of the shopping centre under construction. At this stage, the commercialisation agents provided very strong support. It should be also highlighted that short-term activities conducted after the trade shows had finished were important.

Stage V (project closure) can be defined with relation to the following activities:

- opening the shopping centre,

- completing all the execution-related and technical processes,

- finishing the commercialisation process,

- settling an account with the financing institution and commencing the process of discharging obligations after the opening,

- testing the processes of shopping centre management.

The developers under research, whose project life cycle was already at a completion stage, basically did not perform any trade show activity. However, due to the fact that at the time of the opening there were some shopping areas that had not been leased yet, the developers declared that they would participate in trade shows in the future in order to:

- inform the market about the fact of opening the shopping centre and effects of that fact,

- speed up the process of concluding rental agreements for the areas which were still not leased after the shopping centre had been opened,

- recommercialisation (leasing some of the areas again following the withdrawal of tenants). 
At the completion stage, the representatives of some of the developers under research participated in the trade shows as visitors alone. It is not practised at this stage to use own stalls in order to avoid a feeling that too intensive marketing activities, relating to the shopping centre that is being promoted, are performed. Such actions - in the market opinion - could result in a negative judgement.

\section{DISCUSSION, CONCLUSIONS AND FUTURE RESEARCH}

The objective of this paper has been accomplished by presenting the activities at the individual stages of the investment project life cycle, which was implemented by domestic developers with little experience, in relation to the trade show activity management at each of the separate stages. The authors of this paper have identified and presented the development project life cycle of a huge shopping centre, which constitutes a copybook example. In Real, especially in the case of the developers that have little experience, the cycle is usually subject to many disruptions, which results in extending the duration of individual stages. It is worth noting that in the retail Real Estate business, the time for the execution of a huge investment project life cycle, which is expected by the market (among others, tenants and financing institutions), as of the date of giving an announcement in the market (stage II), is 4 to 7 years - the similar time period has been achieved in the results of the research (table 1). As a consequence of delay in project execution, a flexible approach to the management of various processes is required, including also the trade show activity process management. Therefore, the trade show activity management is by its very nature dynamic.

In general, one can observe that in the trade show activity management there are three characteristic periods, related to the progress in the investment project execution. The first period involves the management of the developer's representative participation in the trade shows, who performs a role of a visitor. The period is preliminary and entails the preparation of the investment project for execution (stage I and II of the project life cycle). Second period of the trade show activity management constitutes the high point in the project life cycle, and involves a one- or two-time trade show performance by a developer (stage III). And finally, third period means a drop in the developer's trade show activity and is connected with the completion of the investment project (stage IV and V). The boundary between second and third period is quite fluid, and it depends on the progress in the project execution. This is the point where the flexibility in the trade show activity management may occur.

The fact that the results presented herein are qualitative makes the research limited, and therefore no generalisation is allowed. However, the research enabled to notice in a long time changes in the activities of the entities in question. The research goal defined herein required to apply qualitative methods.

It can be expected that trade show activity management performed by experienced retail Real Estate developers, implementing many investment projects at the same time, at various stages of sophistication, would be different. A substantial quantity of projects under implementation and, additionally, a broader scope of services provided by such developers determine a more complicated, multifactor relationship between a life cycle of a particular project and a trade show activity. However, this problem is not the subject matter of the research presented in this paper. The authors recommend that the abovementioned issue should be dealt with in the future. Further research related to the trade 
show activity management of retail Real Estate developers may focus on a trade show performance by a particular developer from the perspective of the management of a promise given to tenants ${ }^{22}$. The management of experiential marketing by the exhibitors representing the business under analysis may constitute yet another, essential research problem.

\section{REFERENCES}

[1] Batko A., Borcuch A., Mochoń A., Piłat-Borcuch M., Świerczyńska-Kaczor U., Rynek targowy: scena wystawców $i$ organizatorów, Wydawnictwo Uniwersytetu HumanistycznoPrzyrodniczego Jana Kochanowskiego, Kielce 2010.

[2] Gębarowski M., Wspótczesne targi. Skuteczne narzędzie komunikacji marketingowej, Regan Press, Gdańsk 2010.

[3] Gębarowski M., Zarządzanie udziałem $w$ targach $w$ kontekście działań marketingowych realizowanych na rynku B2B, [in:] Zarzadzanie wobec wspótczesnych wyzwań społecznoekonomicznych. Księga jubileuszowa dedykowana Profesorowi Janowi Adamczykowi, ed. J. Wiażewicz, Oficyna Wydawnicza Politechniki Rzeszowskiej, Rzeszów 2013, p. 75-83.

[4] Gębarowski M., Siemieniako D., Targi rynku nieruchomości handlowych $w$ świetle badań metoda obserwacji uczestniczacej, "Marketing i Rynek" 2014/9, p. 33-39.

[5] Gronroos C., Marketing as promise management: regaining customer management for marketing, "Journal of Business \& Industrial Marketing" 24/5 (2009), p. 351-351.

[6] Hällgren M., Söderholm A., Project-as-practice: New approach, new insights, [in:] The Oxford handbook of project management, ed. P.W.G. Morris, J.K. Pinto, J. Söderlund, Oxford University Press, Oxford 2012, p. 500-516.

[7] Hodgson D., Cicmil S., The politics of standards in modern management: Making 'the project' a reality, "Journal of Management Studies" 44/3 (2011), p. 431-450.

[8] Jensen S., Nuneva A., Trade show as a brand management instrument in the B2B sector, [in:] Trade Show Management, ed. M. Kirchgeorg, W. M. Dornscheidt, W. Giese, N. Stoeck, Gabler, Wiesbaden 2005, p. 1083-1099.

[9] Kotler Ph., Pfoertsch W., B2B Brand Management, Springer, Berlin-Heidelberg 2006.

[10] Lester A., Project Management, Planning and Control: Managing Engineering, Construction and Manufacturing Projects to PMI, APM and BSI Standards, Butterworth-Heinemann, Jordan Hill 2007.

[11] Lindkvist L., Söderlund J., Tell F., Managing product development projects: On the significance of fountains and deadlines, "Organization Studies" 19/6 (1998), p. 931-951.

[12] Mainela T., Ulkuniemi P., Personal interaction and customer relationship management in project business, "Journal of Business \& Industrial Marketing" 28/2 (2013), p. 103-110.

[13] Meng X., The effect of relationship management on project performance in construction, "International Journal of Project Management" 30/2 (2012), p. 188-198.

[14] Nowe obiekty zmieniaja układ sił na mapach handlowych głównych miast, "Rynek handlowy w Polsce - II kw. 2013”, Jones Lang LaSalle, p. 2, http://qbusiness.pl/uploads/ Raporty/jllhandel22013.pdf (accessed on: 8 July 2014).

[15] Odeh A.M., Battaineh, H.T., Causes of construction delay: traditional contracts, "International Journal of Project Management" 20/1 (2002), p. 67-73.

[16] Packendorff J., Inquiring into the temporary organization: New directions for project management research, "Scandinavian Journal of Management" 11/4 (1995), p. 319-333.

[17] Pelsmacker de P., Geuens M., Bergh van den J., Marketing Communications: A European Perspective, Pearson Education, Harlow 2010.

${ }^{22}$ C. Gronroos, Marketing as promise management: regaining customer management for marketing, "Journal of Business \& Industrial Marketing”, 24/5 (2009), p. 356. 
[18] Siemieniako D., Model zarządzania lojalnościa relacyjna oparta na zobowiązaniu $w$ zwiazkach ustugowych, "Marketing i Rynek" 2012/5, p. 8-14.

[19] Siskind B., Powerful Exhibit Marketing: The Complete Guide to Successful Trade Shows, Conferences, and Consumer Shows, John Wiley \& Sons Canada, Mississauga 2005.

[20] Smith P.R., Zook Z., Marketing Communications: Integrating Offline and Online with Social Media, Kogan Page, London 2011.

[21] Söderlund J., Theoretical foundations of project management: Suggestions for a pluralistic understanding, [in:] The Oxford handbook of project management, ed. P.W.G. Morris, J.K. Pinto, J. Söderlund, Oxford University Press, Oxford 2011, p. 37-64.

[22] Sułkowski Ł., Paradygmaty nauk o zarządzaniu, "Współczesne Zarządzanie" 2013/2, p. 17-26.

[23] Westland J., The Project Management Life Cycle: Complete Step-by-Step Methodology for Initiating, Planning, Executing \& Closing a Project Successfully, Kogan Page, London 2006.

[24] Woodside A.G., Wilson E.J., Case study research methods for theory building, "Journal of Business and Industrial Marketing" 18/6 (2003), p. 493-508.

\section{PROCES DYNAMICZNEGO ZARZĄDZANIA AKTYWNOŚCIĄ TAR- GOWĄ W CYKLU ŻYCIA PROJEKTU DEVELOPERSKIEGO}

$\mathrm{W}$ artykule przedstawiono problematykę zarządzania aktywnością targową w odniesieniu do cyklu życia projektu deweloperskiego dużego centrum handlowego. Zmienność tego cyklu w branży nieruchomości handlowych wymaga dynamicznego i elastycznego podejścia do zarządzania udziałem w wydarzeniach wystawienniczych, który jest złożonym procesem, składającym się z kilku etapów. Celem artykułu jest rozpoznanie aktywności targowej mało doświadczonych (tj. dopiero wchodzących na rynek) deweloperów nieruchomości handlowych, rozciągniętej w czasie trwania pełnego cyklu życia projektu inwestycyjnego dużego centrum handlowego. Przyjęto, że cykl życia projektu deweloperskiego nieruchomości handlowych składa się z pięciu etapów: inicjacja projektu, planowanie projektu, realizacja przygotowawcza, realizacja właściwa, zamknięcie projektu. Każdy z etapów przedstawiono poprzez zdefiniowanie procesów zarządzania projektem właściwych dla poszczególnych etapów. W badaniu uwzględniono aktywność 6 mało doświadczonych deweloperów dużych centrów handlowych, w okresie około 2,5 roku. W tym czasie uczestniczyli oni w 7 kolejnych targach rynku nieruchomości handlowych. Wykorzystano jakościowe metody badawcze: mystery visitor (jako rodzaj obserwacji uczestniczącej) oraz wywiady swobodne. Zastosowano także analizę materiałów informacyjnych i reklamowych badanych deweloperów. Przedstawiono analizę powiązania działań badanych podmiotów w odniesieniu do pięciu etapów cyklu życia projektu deweloperskiego, z zarządzaniem aktywnością targową na każdym z tych etapów. Wskazano na dominujące, podczas realizacji poszczególnych faz, płaszczyzny aktywności targowej wystawców (spośród trzech rodzajów wymiarów: informacyjnego, promocyjnego, handlowego).

Słowa kluczowe: targi B2B, zarządzanie aktywnością targową, cykl życia projektu, deweloper nieruchomości handlowych, obserwacja uczestnicząca.

\section{DOI: $10.7862 /$ rz.2014.mmr.38}

Tekst złożono w redakcji: wrzesień 2014

Przyjęto do druku: październik 2014 